\title{
Pengaruh Modal Kerja, Likuiditas, Struktur Modal Terhadap Profitabilitas Perusahaan Manufaktur 2012 - 2014
}

\author{
Emillia Sastra \\ (Fakultas Ekonomi Universitas Tarumanagara, Jakarta) \\ Email:emillias@fe.untar.ac.id
}

\begin{abstract}
The purpose of this empirical research is to obtain empirical evidence about the influence of working capital, liquidity and capital structure on the profitability on manufacturing companies listed on the stock exchange from 2012-2014. This research used manufacturing companies for total of 198 data in three years and that were selected using purposive sampling method. The data used in this research are secondary data in the form of financial statements. The results showed that the working capital and liquidity has a positive significant effect on profitability, capital structure does not have a significant effect on profitability. The testing showed independent variable have a significant impact on the profitability and show that the correlation of the independent variables have strong relationship to the dependent variable. Testing results show that the coefficient of determination of $55.1 \%$, dependent variable is affected by the independent variable, while the remaining $44,9 \%$ is explained by other variables.
\end{abstract}

Keywords: Profitability, Working Capital, Liquidity, Capital Structure.

\begin{abstract}
Abstrak: Penulisan paper ini adalah bertujuan untuk memperoleh bukti empiris mengenai pengaruh modal kerja, likuiditas dan struktur modal terhadap profitabilitas pada perusahaan manufaktur di Bursa Efek Indonesia dari tahun 2012-2014. Penelitian ini menggunakan data perusahaan manufaktur dengan total 198 data selama tiga tahun dan telah diseleksi menggunakan metode purposive sampling. Data yang digunakan adalah data sekunder berupa laporan keuangan. Hasil penelitian menunjukkan bahwa modal kerja dan likuiditas memiliki pengaruh signifikan positif terhadap profitabilitas, sedangkan struktur modal tidak memiliki pengaruh secara signifikan terhadap profitabilitas dan menunjukkan bahwa semua variabel independen memiliki pengaruh yang signifikan terhadap profitabilitas. Pengujian korelasi menunjukkan bahwa variabel independen memiliki hubungan yang kuat terhadap variabel dependen. Pengujian koefisien determinasi menyatakan hasil 55.1\%, variabel dependen dipengaruhi oleh variabel independen, sisanya sebesar $44,9 \%$ dipengaruhi variabel-variabel lain.
\end{abstract}

Kata Kunci: Profitabilitas, Modal Kerja, Likuiditas, Struktur Modal.

\section{PENDAHULUAN}

Keberhasilan suatu perusahaan seringkali dinilai dari besarnya profitabilitas yang dilaporkan. Profitabilitas yang tinggi dapat mencerminkan kinerja perusahaan yang baik, keunggulan dalam persaingan usaha serta mempengaruhi kelangsungan hidup suatu perusahaan. Tingkat profitabilitas yang semakin tinggi menunjukkan kinerja perusahaan semakin baik dan dengan demikian dapat menarik investor. Persaingan bisnis yang ketat ini membuat para pengusaha berlomba-lomba dalam memikirkan cara agar mereka 
mendapatkan profit yang besar dengan sedikit mengurangi berbagai pertimbanganpertimbangan khusus dalam mengambilan keputusan tersebut. Resiko jangka panjang mungkin akan dirasakan perusahaan yang tidak menimbang baik-baik langkah apa yang harus diambil agar profitabilitas perusahaannya dapat meningkat dan dapat bersaing dengan perusahaan kompetitor di pasar. Era globalisasi ini juga memaksa perusahaan untuk selalu mengembangkan cara dalam berbisnis dan memperoleh profit yang besar. Selain itu profitabilitas menjadi tolok ukur dan pertimbangan yang harus diperhatikan perusahaan agar menarik para investor untuk menanamkan modalnya.

Profitabilitas adalah kemampuan perusahaan memperoleh laba dalam hubungannya dengan penjualan, total aktiva maupun modal sendiri (Sartono, 2010). Dengan mengetahui pengaruh dari masing-masing faktor terhadap profitabilitas, perusahaan dapat menentukan langkah untuk mengatasi masalah masalah dan meminimalisir dampak negatif yang yang timbul. Menurut Husnan (Husnan dan Pudjiastuti, 2012) Profitabilitas yang tinggi menjadi daya tarik bagi investor atau calon investor karena merupakan bagian keuntungan yang akan diterimanya sebagai pemegang saham di perusahaan tersebut.

Faktor lain yang mendukung dilakukannya penelitian tentang profitabilitas ini adalah bahwa pada dasarnya investor tentunya ingin mendapatkan return yang besar, sebagian besar berharap mendapat dividen tunai setiap tahunnya, tetapi harapan investor tersebut tidak hanya dapat diwujudkan dengan angka profitabilitas yang tinggi. Hal ini memungkinkan perusahaan mendapatkan angka profitabilitas yang tinggi yang dikarenakan terdapat penjualan yang besar didukung angka inventory turnover yang tinggi, tetapi hal tersebut belum bisa menjanjikan investor mendapatkan return atau dividen pada tahun itu dikarenakan mungkin saja penjualan yang terjadi adalah sebagaian besar berupa piutang yang tidak pasti dilunasi kapan waktunya dan bisa jadi terjadi piutang tidak tertagih yang besar.

Penelitian ini mengambil responden perusahaan manufaktur dikarenakan perusahaan manufaktur memiliki struktur keuangan yang kompleks dan memiliki urutan kegiatan mulai dari produksi sampai dengan penjualan. Bagi pimpinan perusahaan, profitabilitas digunakan sebagai tolok ukur berhasil atau tidak perusahaan yang dipimpinnya. Jika faktor-faktor yang diteliti kurang atau tidak diperhatikan oleh perusahaan, maka perusahaan diharapkan dapat memperbaiki manejerial dan kebijakan yang akan diambil agar perusahaan dapat memiliki profitabilitas yang diharapkan. Manfaat bagi karyawan perusahaan adalah melalui profitabilitas yang tinggi, perusahaan berkesempatan untuk meningkatkan gaji karyawan dan kesejahteraan karyawan lebih baik. Bagi para calon investor adalah agar investor dapat memilih dan memutuskan dengan benar perusahaan yang akan dipilih untuk menginvestasikan dan dan memperoleh return yang memuaskan. Namun investor juga perlu mengetahui bahwa ada faktor selain profitabilitas yang mempengaruhi return yang akan mereka dapatkan.

\section{KAJIAN TEORI}

\section{Profitabilitas}

Kekayaan para pemegang saham atau pemilik perusahaan (stakeholder) selalu menjadi fokus utama dari setiap perusahaan. Meningkatkan profitabilitas perusahaan adalah salah satu upaya dalam mencapai tujuan perusahaan tersebut (Brigham dan Houston, 2009). Dalam menilai tingkat profitabilitas yang didapatkan dari perusahaan, dapat membandingkan profitabilitas dengan beberapa akun di laporan keuagan, perbandingan ini 
disebut rasio profitabilitas. Adapun tingkat profitabilitas perusahaan dapat diukur melalui rasio profitabilitas atau rasio rentabilitas antara lain : Margin Laba Kotor (Gross Profit Margin - GPM), Margin Laba Bersih (Net Profit Margin - NPM), Return On Equity (ROE), Return on Assets (ROA), Return on Investment (ROI), dan Earning Power (EP).

Pendekatan Du Pont menjelaskan ROI sebagai kemampuan total aktiva menghasilkan laba melalui keterkaitan profit margin dengan turnover of operating assets (Weston, 1997). Sistem Du Pont melakukan analisis profitabilitas dan pengembalian investasi dengan memperhatikan efisiensi penggunaan modal dan pengaruhnya dalam menentukan profitabilitas harta. Analisis ini dapat dipakai untuk menilai kinerja masing-masing produk yang dihasilkan perusahaan, dipakai untuk keperluan kontrol dan keperluan perencanaan serta dasar pengambilan keputusan perusahaan.

Keunggulan pengukuran profitabilitas (Munawir, 2007) adalah profitabilitas dapat dipakai dalam memperoleh rasio industry, yaitu apabila tersedia data industry. Suatu perusahaan dapat diukur dan dibandingkan terhadap perusahaan lain yang sejenis, sehingga dapat diketahui apakah perusahaan mencapai standar atau di bawah standar industri. Melalui pembanding ini, perusahaan juga dapat mengetahui kelemahan dan kekuatan dirinya apabila dibanding perusahaan dalam industri serta mencari jalan keluar atas potensi yang dapat dikembangkan.

Adapun kelemahan dari pengukuran profitabilitas adalah tidak akuratnya proses membandingkan rate of return suatu perusahaan dengan perusahaan lain yang sejenis karena terdapat perbedaan praktek akuntansi oleh setiap perusahaan. Kelemahan lainnya juga dapat terjadi pada adanya fluktuasi nilai uang (daya beli) dimana keadaan inflasi membuat daya beli menjadi berubah dan akan berpengaruh dalam perhitungan profit margin dan investment turnover. Investor perlu mencermati faktor lainnya yang dapat memimplikasi return yaitu resiko bisnis, inflasi, tingkat suku bunga, resiko pasar, ukuran perusahaan, dan kondisi ekonomi selain kinerja perusahaan dari profitabilitas (Rosa dan Mulyani, 2013).

Ditinjau dari fungsi manajer, maka manajer akan dimotivasi untuk dapat memanfaatkan dana yang tersedia secara maksimal untuk meningkatkan kinerja perusahaan melalui perolehan laba atau profitabilitas. Perolehan laba ini nantinya akan dipakai oleh manajer untuk melunasi pinjaman atau hutang yang berasal dari luar dan sebagian untuk perusahaan (Wiranata dan Nugrahanti, 2013). Pernyataan ini menyatakan bahwa terdapat hubungan antara kemampuan profitabilitas yang dapat mempengaruhi kemampuan likuiditas perusahaan.

\section{Modal Kerja}

Modal kerja atau working capital adalah modal yang diinvestasikan perusahaan dalam asset lancar, yang akan digunakan untuk membiayai operasional perusahaan sehari-hari serta dapat dikonversikan menjadi kas dalam waktu kurang dari satu tahun atau jangka waktu pendek. Modal kerja yang dipakai pada penelitian ini adalah nilai modal kerja bruto menurut konsep kuantitatif, yang meliputi seluruh kepemilikan aktiva lancar perusahaan yang dikelola secara optimal untuk membiayai operasional perusahaan. Adapaun modal kerja bruto yang dimaksud mencakup kas, piutang dan persediaan. Kas dan surat berharga adalah modal kerja yang likuid dan sangat penting bagi perusahaan dalam segala kondisi ketidakpastian, Fokus utama perusahaan dalam mengelola kas adalah memastikan kecukupan saldo kas perusahaan untuk memenuhi kewajibannya. 
Piutang merupakan salah satu jenis dan transaksi akuntansi yang memiliki pengertian penagihan kepada konsumen yang timbul dari penjualan barang atau layanan jasa dengan sistem kredit. Adapaun ketentuan pembatasan kredit, volume penjualan kredit, kebijaksanaan pengumpulan piutang, syarat pembayaran kredit, dan kebiasaan pelunasan menjadi faktor yang menentukan seberapa besar dana perusahaan yang terikat dalam piutang (Riyanto, 2011). Kondisi persyaratan pembayaran yang longgar menandakan semakin besarnya jumlah piutang yang dapat terjadi.

Bagi sebagian besar perusahaan industri, persediaan merupakan investasi yang terbesar dalam asset lancar perusahaan dan hal ini membuat modal yang tertanam pada persediaan tidak bisa dipakai untuk kepentingan lainnya. Dalam mengelola persediaan seringkali perusahaan memerlukan keberadaan safety stock atau persediaan minimal, mulai dari persediaan bahan mentah, persediaan bahan dalam proses dan persediaan barang jadi yang diperlukan untuk memastikan dan mempertahankan keberlangsungan usaha perusahaan (Jufrizen, 2014). Rasio perputaran persediaan dipakai untuk menentukan jumlah modal yang terikat di dalamnya. Semakin besar rasio menunjukkan semakin cepat perputaran persediaan yang berarti semakin kecil modal yang perlu diinvestasikan dalam persediaan.

Modal kerja menurut konsep kualitatif dapat dikaitkan dan diartikan sebagai besarnya jumlah hutang lancar atau hutang yang perlu untuk segera dilunasi. Perusahaan perlu mencadangkan sebagian dari asset lancar untuk membiayai pelunasan hutang lancar dan untuk menjaga likuiditasnya maka bagian aktiva lancar ini tidak dipergunakan untuk operasional perusahaan (Riyanto, 2011). Modal kerja menurut konsep ini dikenal juga dengan modal kerja neto (net working capital).

\section{Likuiditas}

Likuiditas adalah kemampuan suatu perusahaan untuk memenuhi kewajiban keuangannya yang harus segera dipenuhi, atau kemampuan perusahaan untuk memenuhi kewajiban keuangannya pada saat di tagih (Riyanto, 2011). Hal ini dihubungkan dengan dasar pemikiran bahwa perusahaan yang tidak memanfaatkan kelebihan aktiva produktif secara efiisien maka terdapat keterbatasan usaha perusahaan dalam menghasilkan profitabilitas.

Rasio lancar (Current ratio) adalah indikasi yang dapat dipakai dalam mengukur likuiditas. Semakin besar rasio lancar menunjukkan kemungkinan yang besar bahwa hutang perusahaan dapat dilunasi pada waktunya dan ini menjadi tanda yang baik bagi para kreditor. Hal ini terutama berlaku bila pimpinan perusahaan menguasai pos-pos modal kerja dengan ketat atau dengan semestinya. Namun current ratio yang tinggi tidak selalu menguntungkan apabila ditinjau dari sudut pemegang saham. Hal ini terjadi apabila terdapat saldo kas yang kelebihan dan jumlah piutang dan persediaan adalah terlalu besar.

Rasio lancar yang rendah mengandung risiko yang lebih besar daripada rasio lancar yang tinggi, tetapi di sisi lain rasio lancar yang rendah mengindikasikan pemakaian aktiva lancar secara efektif oleh perusahaan. Pemakaian aktiva yang efektif adalah pemakaian berdasarkan pada keperluan minimum dan oleh karenanya perputaran piutang dari persediaan dapat dimaksimalkan. Semakin likuid sebuah perusahaan, kemungkinan pembayaran dividen yang dilakukan perusahaan tersebut akan semakin besar. Sehingga likuiditas memiliki pengaruh positif dan signifikan terhadap kepuasan pemegang saham atau pemilik perusahaan (Wicaksana, 2012).

\section{Struktur Modal}


Struktur modal (capital structure) adalah struktur pembelanjaan permanen perusahaan yang mencakup atas hutang jangka panjang dan modal sendiri (Rodoni dan Nassaruddin, 2007). Perusahaan dengan jumlah utang yang tinggi akan beresiko untuk melanggar perjanjian utang dengan kreditur karena jumlah aktiva yang dimiliki tidak mampu menjamin utang perusahaan. Selain itu perusahaan juga akan dibebankan biaya bunga yang tinggi dan akan menyebabkan nilai buku ekuitas perusahaan negatif (Andre, 2013).

Menurut penelitian sebelumnya (Wibowo dan Wartini, 2012), Leverage tidak memiliki pengaruh pada profitabilitas karena sumber dana perusahaan manufaktur tidak bergantung pada dana pinjaman atau utang. Perusahaan manufaktur yang terdaftar di BEI pada umumnya lebih banyak menggunakan sumber dana dari dalam perusahaan daripada dana pinjaman, sehingga besar kecilnya jumlah utang yang dimiliki oleh perusahaan tidak akan mempengaruhi besar kecilnya profitabilitas yang diperoleh perusahaan. Sehingga perusahaan tidak perlu meningkatkan nilai pinjamannya untuk meningkatkan profitabilitas, karena profitabilitas perusahaan tidak dipengaruhi oleh leverage.

Laba ditahan atau retained earning adalah sebagian laba hasil dari operasional perusahaan yang akan dipergunakan kembali sebagai dana untuk operasional perusahaan selanjutnya dan dapat dikumpulkan sebagai dana cadangan bagi rencana strategis perusahaan di masa yang akan datang. Hutang atau kewajiban adalah sumber dana perusahaan yang bersumber dari pinjaman yaitu berasal dari pihak lainnya namun memiliki kepentingan secara langsung dengan perusahaan. Apabila perusahaan menggunakan laba ditahan sebagai penambah modalnya maka hal tersebut dapat mengurangi hutang yang dimiliki perusahaan. Hal ini sesuai dengan pecking order theory, dimana perusahaan lebih menyukai pembiayaan dengan sekuritas paling aman yaitu laba ditahan, kemudian baru penggunaan dana ekstenal dengan hutang dan penjualan saham (Damayanti, 2013).

Mireku (Mireku et al., 2014) menyampaikan hasil penelitian tentang hubungan struktur modal dan kinerja keuangan dengan mengambil kejadian di Ghana dengan periode 2002-2007. Kelebihan tulisan ini adalah bahwa peneliti menggunakan dua definisi struktur modal, yaitu (1) berdasarkan nilai pasar, dan (2) berdasarkan nilai buku. Penelitian menghasilkan kesimpulan banyak kinerja perusahaan mempunyai hubungan negative dengan leverage yang merupakan representasi struktur modal. Hal ini terjadi karena perusahaan dengan sedikit utang lebih banyak mendapatkan profit margin dan lebih baik kinerja keuangannya. Selain itu struktur modal yang didasarkan pada nilai pasar yang mempunyai hubungan yang lebih kuat dengan profitabilitas dibandingkan yang didasarkan nilai buku.

Secara grafikal kerangka pemikiran paper ini yaitu pengaruh antara variabel independen dan variabel dependen, yaitu profitabilitas dapat digambarkan pada gambar berikut:

\section{Gambar 1.}

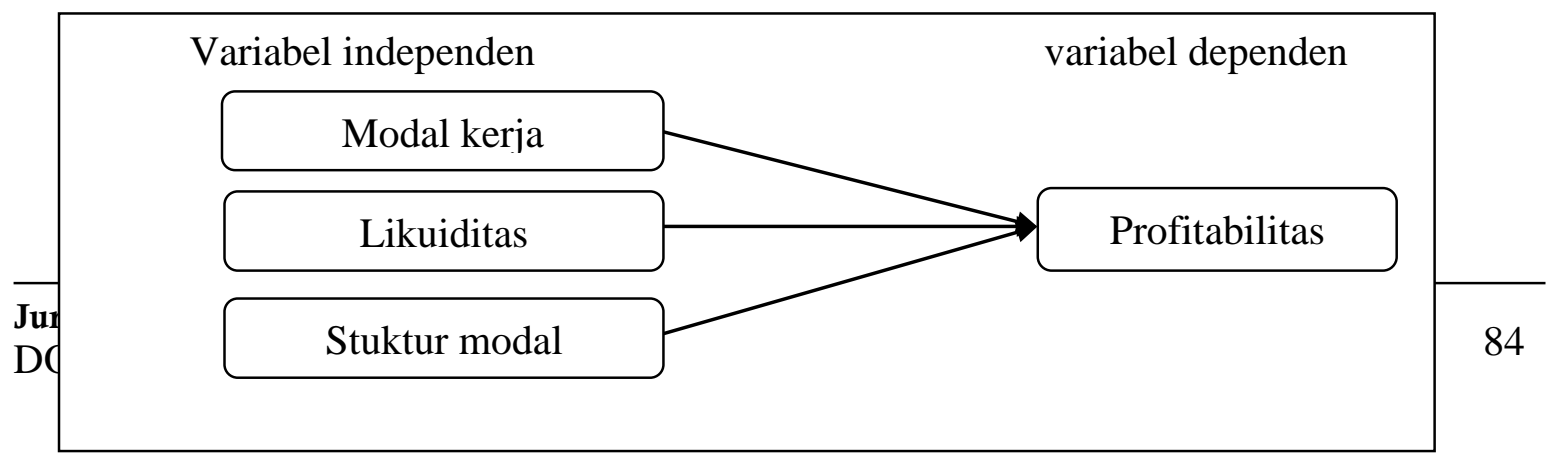


Hipotesis yang dikembangkan di dalam paper ini adalah:

Ha1: Modal kerja memiliki pengaruh yang positif terhadap profitabilitas perusahaan manufaktur di BEI 2012-2014.

Ha2: Likuiditas memiliki pengaruh yang positif terhadap profitabilitas perusahaan manufaktur di BEI 2012-2014.

Ha3: Struktur modal tidak memiliki pengaruh yang positif terhadap profitabilitas perusahaan manufaktur di BEI 2012-2014.

\section{METODE}

Penelitian ini memilih sampel penelitian dengan metode tidak acak atau metode purposive sampling yaitu teknik sampling yang mengambil sampelnya dengan pertimbangan dan kriteria tertentu. Berikut adlah kriteria dalam pengambilan sampel pada penelitian ini: (a) Perusahaan manufaktur yang terdaftar di Bursa Efek Indonesia pada tahun 2012-2014 secara berturut-turut, (b) perusahaan memiliki laporan keuangan yang lengkap dari tahun 2012-2014, (c) perusahaan manufaktur yang menggunakan mata uang Rupiah, (d) yang tidak mengalami kerugian.

Variabel profitabilitas dalam penelitian ini diukur dengan Return on Assets (ROA). ROA dipakai untuk menghubungkan keuntungan yang diperoleh dari operasi perusahaan dengan jumlah aktiva yang digunakan untuk menghasilkan keuntungan operasi tersebut. Variabel modal kerja akan dihitung dengan rumus perputaran persediaan yaitu dengan membandingkan modal penjualan (cost of goods sold) dengan persediaan. Variabel likuiditas dalam penelitian ini diukur dengan rasio lancar, yaitu dengan membandingkan antara aktiva lancar dan hutang lancarnya. Untuk mengukur efektifitas penggunaan struktur modal akan diukur dengan menggunakan rasio leverage yaitu Debt to Equity Ratio (DER) yaitu membandingkan antara jumlah hutang dan modal sendiri.

Data yang dipakai dalam penelitian ini adalah data sekunder, yaitu laporan keuangan tahunan (annual report) dari semua perusahaan manufaktur yang terdaftar di Bursa Efek Indonesia dan yang telah dipublikasikan kepada pemegang saham (shareholders). Metode pengumpulan data pada penelitian ini dilakukan dengan penelitian lapangan dan penelitian kepustakaan.

Teknik pengolahan data yang digunakan dalam penelitian ini adalah statistik. Adapun pengolahan data dilakukan melalui uji statistik deskriptif dan uji asumsi klasik, kemudian diolah dengan teknik analisis regresi linear berganda (multiple linier regression). Beberapa uji asumsi klasik yang akan digunakan dalam penelitian ini antara lain uji normalitas, uji multikoleniaritas, uji heteroskedastisitas dan uji autokorelasi. Hipotesis dalam penelitian ini akan diuji dengan menggunakan uji statistik yaitu uji koefisien determinasi (Adj $R^{2}$ ), uji parsial (uji statistik t), dan uji pengaruh simultan (uji $F$ ). 


\section{HASIL DAN PEMBAHASAN}

Berdasarkan proses pemilihan sampel, maka data-data yang berhasil dikumpulkan dalam penelitian ini adalah sebanyak 66 perusahaan pertahun atau sebanyak 198 perusahaan selama tiga tahun, yaitu dari tahun 2012-2014. Analisis data yang dilakukan dengan statistik deskriptif menafsirkan besarnya nilai tertinggi dan nilai terendah, mean dan standar deviasi dari Modal Kerja, Likuiditas, Struktur modal dan profitabilitas

Sebelum dilakukan analisis hubungan antar variabel dengan menggunakan uji regresi linier berganda (multiple linear regression), terlebih dahulu dilakukan uji asumsi untuk membuktikan bahwa pengolahan data penelitian ini layak menggunakan metode statistik prametrik. Uji asumsi klasik adalah persyaratan statistik yang harus dipenuhi pada analisis regresi linear berganda yang berbasis ordinary least square (OLS).

Uji asumsi yang pertama adalah uji normalitas. Uji normalitas berfungsi untuk menguji apakah terdapat variabel pengganggu atau residual memiliki distribusi normal dalam sebuah model regresi,. Adapun dua cara yang dipakai untuk mengetahui apakah residual berdistribusi normal atau tidak yaitu dengan analisis grafik atau uji statistik. Analisis statistik akan dilakukan dengan cara uji Kolmogorov-Smirnov. Apabila nilai signifikansi $<0,05$ maka distribusi data residual tidak normal dan apabila nilai signifikansi $>0,05$ maka data residual berdistribusi normal. Hasil uji Kolmogorov-Smirnov pada Tabel 1 menunjukkan bahwa nilai signifikansi $>0,05$, sehingga dapat disimpulkan bahwa data residual berdistribusi normal. Berikut ini adalah hasil uji normalitas data dengan analisis grafik dan uji Kolmogorov-Smirnov:

Tabel 1.

Uji Normalitas Kolmogorov-Smirnov

\begin{tabular}{|c|c|c|}
\hline \multicolumn{3}{|c|}{ One-Sample Kolmogorov-Smirnov Test } \\
\hline & & $\begin{array}{l}\text { Unstandardized } \\
\text { Residual }\end{array}$ \\
\hline & & 198 \\
\hline \multirow{2}{*}{ Normal Parameters ${ }^{\mathrm{a}, \mathrm{b}}$} & Mean & .0000000 \\
\hline & Std. Deviation & .07758664 \\
\hline \multirow[t]{3}{*}{ Most Extreme Differences } & Absolute & .216 \\
\hline & Positive & .216 \\
\hline & Negative & -.159 \\
\hline \multicolumn{2}{|l|}{ Kolmogorov-Smirnov Z } & 3.034 \\
\hline \multicolumn{2}{|l|}{ Asymp. Sig. (2-tailed) } & .203 \\
\hline \multicolumn{3}{|l|}{ a. Test distribution is Normal. } \\
\hline
\end{tabular}

Sumber : Pengolahan data sekunder dengan SPSS 20.00

Uji asumsi selanjutnya adalah uji multikolinearitas. Uji ini bertujuan untuk menguji apakah model regresi ditemukan adanya korelasi antar variabel bebas (independen). Hasil dari koefisien regresi tidak tentu dan kesalahan standar tidak terhingga dapat 
mengakibatkan perusahaan salah mengambil keputusan, sehingga menerima hipotesis yang ditolak.

Berdasarkan hasil output data Tabel 2 maka didapatkan bahwa nilai VIF variabel Modal kerja : 1.005 , nilai VIF variabel Likuiditas : 1.010, dan nilai VIF variabel Struktur modal : 1.013, dengan demikian semua nilai VIF $<10$, ini berarti tidak terjadi multikolonieritas, sehingga dapat disimpulkan bahwa uji multikolonieritas terpenuhi.

Tabel 2.

Uji Multikolinearitas

\begin{tabular}{|l|l|r|r|}
\hline \multirow{2}{*}{ Model } & \multicolumn{2}{|c|}{ Collinearity Statistics } \\
\cline { 3 - 4 } 1 & Tolerance & \multicolumn{2}{|c|}{ VIF } \\
\cline { 3 - 4 } & Modal kerja & .995 & 1.005 \\
\cline { 2 - 4 } & Likuiditas & .990 & 1.010 \\
\cline { 2 - 4 } & Struktur modal & .988 & 1.013 \\
\hline
\end{tabular}

Sumber : Pengolahan data sekunder dengan SPSS 20.00

Jika probabilitas masing-masing variabel independen $>0,05$ maka dapat disimpulkan tidak terjadi heteroskedastisitas dalam model regresi. Dengan menggunakan metode Glejser dalam uji heterokedastisitas pada Tabel 3, maka dapat disimpulkan bahwa model regresi ini terbebas dari heterokedastisitas karena variabel Modal kerja, Likuiditas, dan Struktur modal memiliki nilai sig masing-masing sebesar 0,$085 ; 0,692 ; 0,372$ dan lebih besar dari 0,05 .

Tabel 3.

Hasil Uji Heteroskedastisitas

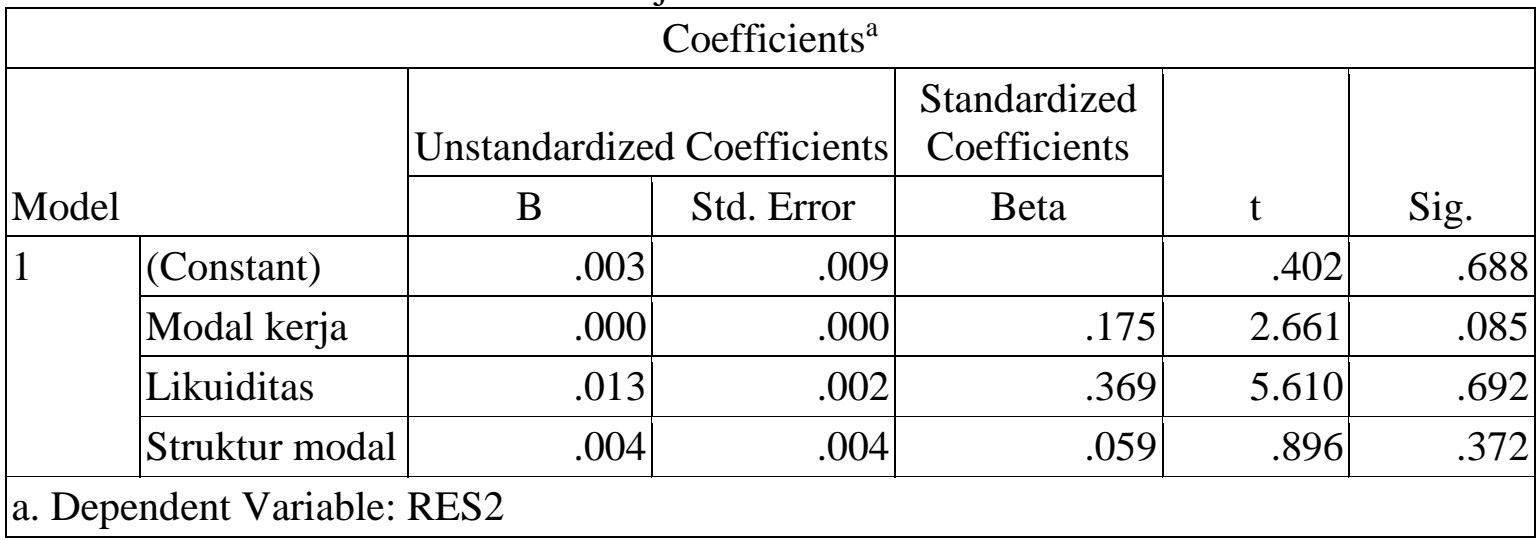

Sumber : Pengolahan data sekunder dengan SPSS 20.00

Uji autokorelasi merupakan pengujian asumsi dalam regresi dimana variabel dependen tidak berkorelasi dengan dirinya sendiri. Untuk menguji apakah adanya autokorelasi dalam penelitian, maka digunakan metode Durbin-Watson (DW test). Berdasarkan hasil pengujian pada Tabel 4 dapat dilihat bahwa nilai Durbin-Watson (DW hitung) sebesar 2.208. Hasil tersebut kemudian dibandingkan dengan hasil yang diperoleh dari tabel statistik Durbin-Watson dengan tingkat signifikasi 0.05, Jumlah data $\mathrm{N}=198$, dan banyaknya variabel bebas independen (bebas) adalah 3 (K-3) maka akan diperoleh 
nilai dL (Batas luar) sebesar 1.736 dan nilai dU (Batas dalam) sebesar 1.797, berarti 4 dL $(4-1.736=2.264)$ dan $4-\mathrm{dU}(4-1.797=2.203)$. Hasil nilai Durbin-Watson lebih besar dari 4 - dU dan kurang dari 4 - dL, maka dapat disimpulkan bahwa tidak terdapat autokorelasi antar nilai residual. Sehingga dapat disimpulkan uji autokorelasi terpenuhi.

Tabel 4.

Uji Autokorelasi

\begin{tabular}{|c|c|c|c|c|c|}
\hline \multicolumn{6}{|c|}{ Model Summary ${ }^{b}$} \\
\hline Model & $\mathrm{R}$ & R Square & $\begin{array}{l}\text { Adjusted R } \\
\text { Square }\end{array}$ & $\begin{array}{l}\text { Std. Error of the } \\
\text { Estimate }\end{array}$ & Durbin-Watson \\
\hline 1 & $.742^{\mathrm{a}}$ & .551 & .544 & .0781842 & 2.208 \\
\hline
\end{tabular}

Sumber : Pengolahan data sekunder dengan SPSS 20.00

Analisis regresi linear berganda digunakan untuk mengetahui pengaruh ukuran perusahaan, struktur modal, kepemilikan institusional, dan likuiditas sebagai variabel independen terhadap profitabilitas sebagai variabel dependen. Berikut adalah model regresi linear berganda berdasarkan data penelitian :

Tabel 5.

Hasil Analisis Regresi Linier berganda

\begin{tabular}{|c|c|c|c|c|c|c|}
\hline \multirow{2}{*}{\multicolumn{2}{|c|}{ Model }} & \multicolumn{2}{|c|}{$\begin{array}{l}\text { Unstandardized } \\
\text { Coefficients }\end{array}$} & \multirow{2}{*}{$\begin{array}{c}\begin{array}{c}\text { Standardized } \\
\text { Coefficients }\end{array} \\
\text { Beta }\end{array}$} & \multirow[b]{2}{*}{$\mathrm{t}$} & \multirow[b]{2}{*}{ Sig. } \\
\hline & & B & Std. Error & & & \\
\hline \multirow[t]{4}{*}{1} & (Constant) & .027 & .011 & & 2.387 & .018 \\
\hline & Modal kerja & .003 & .000 & .561 & 11.631 & .000 \\
\hline & Likuiditas & .028 & .003 & .443 & 9.155 & .000 \\
\hline & Struktur modal & -.010 & .006 & -.087 & -1.793 & .075 \\
\hline
\end{tabular}

a. Dependent Variable: Profitabilitas

Sumber : Pengolahan data sekunder dengan SPSS 20.00

Berdasarkan Tabel 5, dapat disusun persamaan regresi linier berganda sebagai berikut :

$$
\begin{aligned}
& Y=a+b_{1} X_{1}+b_{2} X_{2}+b_{3} X_{3}+e \\
& Y=0.027+0.003 X_{1}+0.028 X_{2}-0.010 X_{3}+0.449
\end{aligned}
$$

Berdasarkan persamaan regresi linier berganda, dapat dilihat bahwa koefisien kostanta (a) adalah sebesar 0.027. Hal ini berarti nilai variabel Profitabilitas (Y) sebesar 0.027 apabila variabel Modal kerja $\left(\mathrm{X}_{1}\right)$, variabel Likuiditas $\left(\mathrm{X}_{2}\right)$ dan variabel Struktur modal $\left(\mathrm{X}_{3}\right)$ tidak ada atau sama dengan nol.

$\beta_{1}=0.003$, artinya apabila variabel Modal kerja $\left(\mathrm{X}_{1}\right)$ meningkat dan variabel Likuiditas $\left(\mathrm{X}_{2}\right)$ serta variabel Struktur modal $\left(\mathrm{X}_{3}\right)$ tetap maka variabel Profitabilitas $(\mathrm{Y})$ akan meningkat sebesar 0.003. $\beta_{2}=0.028$, artinya apabila variabel Likuiditas $\left(\mathrm{X}_{2}\right)$ meningkat dan variabel Modal kerja $\left(\mathrm{X}_{1}\right)$ serta variabel Struktur modal $\left(\mathrm{X}_{3}\right)$ tetap maka 
variabel Profitabilitas (Y) akan meningkat sebesar 0.028. $\beta_{2}=-0.010$, artinya apabila variabel Struktur modal $\left(\mathrm{X}_{3}\right)$ meningkat dan variabel Modal kerja $\left(\mathrm{X}_{1}\right)$ serta variabel Likuiditas $\left(\mathrm{X}_{2}\right)$ tetap maka variabel Profitabilitas $(\mathrm{Y})$ akan menurun sebesar -0.010.

Koefisien determinasi $\left(\mathrm{R}^{2}\right)$ dipakai untuk mengukur ketepatan model atau formula dalam menjelaskan keterkaitan variabel dependen. Nilai $\mathrm{R}$ ( $R$ square) yang mendekati satu menunjukkan bahwa variabel independennya memiliki hubungan yang erat terhadap variabel dependen dan dapat menyediakan cukup informasi untuk memprediksi variabelvariabel dependen. Berdasarkan hasil olahan data pada Tabel 6 menunjukkan bahwa besarnya korelasi (R) variabel independen Struktur modal, Modal kerja dan Likuiditas secara bersama-sama terhadap variabel dependen Profitabilitas (Y) adalah sebesar 0.742 yang menandakan hubungan kuat. Sedangkan koefisen determinan (R square) sebesar 0.551 atau $55.1 \%$, menunjukkan bahwa Profitabilitas (Y) dipengaruhi sebesar 55.1\% oleh ketiga variabel independen Struktur modal, Modal kerja dan Likuiditas dan sisanya yaitu sebesar $44.9 \%$ dipengaruhi oleh faktor lainnya.

Tabel 6.

Koefisien Determinan

\begin{tabular}{|c|c|c|c|c|}
\hline \multicolumn{5}{|c|}{ Model Summary } \\
\hline Model & $\mathrm{R}$ & R Square & Adjusted R Square & $\begin{array}{l}\text { Std. Error of the } \\
\text { Estimate }\end{array}$ \\
\hline 1 & $.742^{\mathrm{a}}$ & .551 & .544 & .0781842 \\
\hline
\end{tabular}

Sumber : Pengolahan data sekunder dengan SPSS 20.00

Uji F (Uji Simultan) mengetahui apakah terdapat pengaruh variabel Modal kerja, Likuiditas dan Struktur modal secara bersama-sama terhadap profitabilitas perusahaan manufaktur di BEI 2012 - 2014. Hasil uji signifikan secara simultan dapat dilihat pada Tabel 7, Uji F dilakukan untuk mengetahui pengaruh variabel Modal kerja, Likuiditas dan Struktur modal terhadap Profitabilitas secara simultan. Nilai Sig. sebesar 0.000 menunjukkan untuk tingkat signifikansi alpha sebesar 0.05 two tailed pasti signifikan. Sedangkan untuk pengujian dengan uji $\mathrm{F}$ adalah dengan membandingkan antara nilai $F_{\text {tabel }}$ dengan $F_{\text {hitung. Nilai }} F_{\text {hitung }}$ sebesar 79.392, $F_{\text {tabel }}$ adalah 2.650. Dengan demikian didapat hasil $\mathrm{F}_{\text {hitung }}$ (79.392) $>\mathrm{F}$ tabel (2.650) maka Ho ditolak dan $\mathrm{H}_{\mathrm{a}}$ diterima. Dapat disimpulkan bahawa Modal kerja, Likuiditas dan Struktur modal secara simultan berpengaruh terhadap profitabilitas perusahaan manufaktur di BEI 2012-2014.

Tabel 7.

Uji F (Uji Simultan)

\begin{tabular}{|l|l|r|r|r|r|r|}
\hline \multicolumn{2}{|c|}{ Model } & $\begin{array}{c}\text { Sum of } \\
\text { Squares }\end{array}$ & df & Mean Square & F & Sig. \\
\hline 1 & Regression & 1.456 & 3 & .485 & 79.392 & $.000^{\mathrm{a}}$ \\
\cline { 3 - 8 } & Residual & 1.186 & 194 & .006 & & \\
\cline { 2 - 7 } & Total & 2.642 & 197 & & & \\
\hline
\end{tabular}




\begin{tabular}{|l|l|r|r|r|r|r|}
\hline \multicolumn{2}{|c|}{ Model } & $\begin{array}{c}\text { Sum of } \\
\text { Squares }\end{array}$ & df & Mean Square & F & Sig. \\
\hline 1 & Regression & 1.456 & 3 & .485 & 79.392 & $.000^{\mathrm{a}}$ \\
\cline { 2 - 7 } & Residual & 1.186 & 194 & .006 & & \\
\cline { 2 - 7 } & Total & 2.642 & 197 & & & \\
\hline
\end{tabular}

Sumber : Pengolahan data sekunder dengan SPSS 20.00

Uji T (Uji Parsial) dilakukan untuk mengetahui pengaruh variabel Modal kerja $\left(\mathrm{X}_{1}\right)$, variabel Likuiditas $\left(\mathrm{X}_{2}\right)$ dan variabel (Struktur modal $\left(\mathrm{X}_{3}\right)$ terhadap Profitabilitas $(\mathrm{Y})$ secara parsial (sendiri-sendiri). Uji t dilakukan dengan membandingkan nilai t hitung dengan $\mathrm{t}$ tabel. Apabila $\mathrm{t}$ hitung $>\mathrm{t}$ tabel, maka dikatakan pengaruhnya signifikan, dan apabila $\mathrm{t}$ hitung $<\mathrm{t}$ tabel, maka dikatakan pengaruhnya tidak signifikan.

Tabel 8.

Uji t (Uji Parsial)

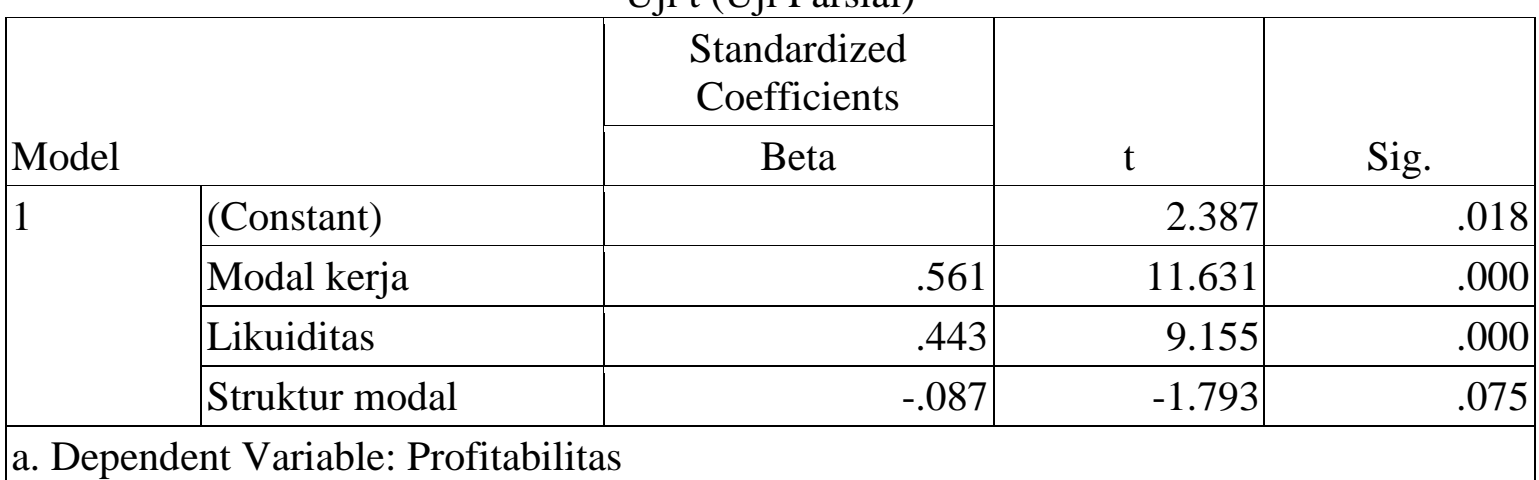

Sumber : Pengolahan data sekunder dengan SPSS 20.00

Hipotesis 1

Ha : Modal kerja memiliki pengaruh yang positif terhadap profitabilitas perusahaan manufaktur di BEI 2012-2014.

Pada Tabel 8 kolom Sig. untuk variabel Modal kerja terlihat nilai Significance sebesar 0,000, karena nilai di bawah 0,05 maka dapat dikatakan signifikan. Pengujian dengan menggunakan uji $\mathrm{t}$ adalah, nilai tabel $\mathrm{t}$ pada alpha 0.05 ( wo tail) $\mathrm{df}=\mathrm{n}-1=198-1=197$ adalah 1.652. sedangkan nilai $\mathrm{t}$ hitung pada Tabel diatas sebesar uji $\mathrm{t}=11.631$. Berarti $t_{\text {hitung }}>\mathrm{t}_{\text {tabel }}$ maka Ha diterima.

Hasil pengujian variabel Modal kerja terhadap profitabilitas secara parsial menunjukkan bahwa modal kerja mempunyai pengaruh positif dan signifikan terhadap profitabilitas pada perusahaan manufaktur di BEI 2012-2014. Dengan demikian dapat disimpulkan bahwa Ha diterima yaitu modal kerja memiliki pengaruh positif terhadap profitabilitas. 
Hipotesis 2

Ha : Likuiditas memiliki pengaruh yang positif terhadap profitabilitas perusahaan manufaktur di BEI 2012-2014,

Pada Tabel 8 kolom Sig. untuk variabel Struktur modal terlihat nilai Significance sebesar 0,000 (0\%), karena nilai di bawah 0,05 (5\%) maka dapat dikatakan signifikan. Pengujian dengan menggunakan uji $\mathrm{t}$ adalah, nilai tabel t pada alpha 0.05 (two tail) $\mathrm{df}=\mathrm{n}-1=198$ $1=197$ adalah 1.652. sedangkan nilai $\mathrm{t}$ hitung pada Tabel diatas sebesar uji $\mathrm{t}=9.155$. Berarti $t_{\text {hitung }}>t_{\text {tabel }}$ maka Ha diterima.

Hasil pengujian variabel Likuiditas terhadap profitabilitas secara parsial menunjukkan bahwa Likuiditas mempunyai pengaruh positif dan signifikan terhadap profitabilitas pada perusahaan manufaktur di BEI 2012-2014. Dengan demikian dapat disimpulkan bahwa Ha diterima yaitu likuditas memiliki pengaruh positif terhadap profitabilitas.

\section{Hipotesis 3}

Ha : Struktur modal tidak memiliki pengaruh yang positif terhadap profitabilitas perusahaan manufaktur di BEI 2012-2014

Pada Tabel 8 kolom Sig. untuk variabel Likuiditas terlihat nilai Significance sebesar 0,075 (7.5\%), karena nilai di atas 0,05 (5\%) maka dapat dikatakan tidak signifikan. Pengujian dengan menggunakan uji $\mathrm{t}$ adalah, nilai tabel t pada alpha 0.05 (two tail) $\mathrm{df}=\mathrm{n}-1=198$ 1=197 adalah -1.652. sedangkan nilai t hitung pada Tabel diatas sebesar uji $\mathrm{t}=-1.793$. Berarti $t_{\text {hitung }}<\mathrm{t}_{\text {tabel }}$ maka Ha diterima.

Hasil pengujian variabel Struktur modal terhadap profitabilitas secara parsial menunjukkan bahwa Struktur modal mempunyai pengaruh negatif dan tidak signifikan terhadap profitabilitas pada perusahaan manufaktur di BEI 2012-2014. Dengan demikian dapat disimpulkan bahwa Ha diterima yaitu struktur modal tidak memiliki pengaruh negatif terhadap profitabilitas.

\section{PENUTUP}

Berdasarkan hasil analisis data dan pembahasan yang telah dikemukankan, maka dapat diambil beberapa kesimpulan sebagai berikut: terdapat pengaruh yang signifikan antara variabel independen secara keseluruhan dengan variabel dependen, atau dengan kata lain terdapat pengaruh antara variabel modal kerja, likuiditas, dan struktur modal terhadap profitabilitas. Secara parsial terdapat pengaruh yang signifikan antara variabel modal kerja dan likuiditas terhadap profitabilitas. Sedangkan struktur modal tidak memiliki pengaruh yang signifikan terhadap profitabilitas.

Modal kerja menjadi sumber dana bagi kehidupan perusahaan sehari-hari atau jangka waktu pendek yaitu dalam kurun waktu satu tahun atau kurang dari satu tahun. Kecukupan modal kerja sangat penting dalam upaya perusahaan memperluas penjualan, meningkatkan produksi serta mencapai target pendapatan dan keuntungan.

Jika modal kerja mengalami kenaikan, maka profitabilitas perusahaan akan meningkat. Jika modal kerja menurun, maka profitabilitas perusahaan juga akan menurun. Pengaruh variabel modal kerja yang signifikan, maka dalam penentuan modal kerja perusahaan, variabel ini termasuk variabel yang menjadi bahan pertimbangan bagi manajemen.

Kemampuan perusahaan untuk menyelesaikan kewajiban jangka pendek atau likuiditas adalah salah satu faktor penilaian perusahaan yang sehat. Perusahaan yang 
memiliki aktiva-aktiva likuid yang besar dapat menunjang kehidupan perusahaan dan dapat menjadi daya tarik bagi para investor. Secara tidak langsung tidak hanya profitabilitas yang mempengaruhi penilaian para stakeholder bagi kesuksesan perusahaan.

Jika likuiditas mengalami kenaikan, maka profitabilitas perusahaan akan meningkat. Jika likuiditas menurun, maka profitabilitas perusahaan juga akan menurun. Pengaruh variabel likuditas signifikan, maka dalam penentuan likuiditas perusahaan, variabel ini termasuk variabel yang menjadi bahan pertimbangan bagi manajemen.

Struktur modal perusahaan merupakan kumpulan dana yang digunakan dan dialokasikan oleh perusahaan dimana dana tersebut diperoleh dari hutang jangka panjang dan modal sendiri. Besar atau kecilnya modal sendiri dan hutang yang diperoleh dapat menunjukan sebesar apa usaha yang akan dijalankan. Besar atau kecil perusahaan tidak mempengaruhi profitabilitas dari perusahaan dari segi presentasi. Pengelolahan dan strategi yang akan mempengaruhi pertumbuhan perusahaan tersebut. Semakin cepat perusahaan bertumbuh maka angka profitabilitas juga akan meningkat dengan sendirinya.

Jika struktur modal mengalami kenaikan, maka profitabilitas perusahaan akan menurun. Jika struktur modal menurun, maka profitabilitas perusahaan akan menaik. Pengaruh variabel struktur modal tidak signifikan, maka dalam penentuan struktur modal perusahaan, variabel ini tidak termasuk variabel yang menjadi bahan pertimbangan bagi manajemen.

Saran yang diberikan bagi penelitian - penelitian selanjutnya adalah pengujian kembali atas variabel-variabel yang tidak terbukti signifikan dalam penelitian ini dengan menggunakan proksi lain dari variabel tersebut. Misalnya variabel modal kerja dalam penelitian ini menggunakan proksi inventory turnover, yang sebenarnya masih banyak proksi lain dalam modal kerja seperti: cash conversion cycle, receivables collection periods, payable deferral period dan lain-lainnya .

Berdasarkan hasil penelitian ini diharapakan agar perusahaan dapat memperhatikan faktor - faktor tersebut agar dapat memaksimalkan profitabilitas perusahaan. Bagi para calon investor atau investor dapat mempertimbangkan ketika ingin berinvestasi pada suatu perusahaan bahwa profitabilitas dapat dipengaruhi banyak hal, sehingga para investor atau calon investor dapat lebih berinvestasi dengan tepat. Bagi akademis dapat dilakukan penelitian terhadap faktor-faktor lain yang mungkin memiliki pengaruh terhadap profitabilitas.

\section{DAFTAR RUJUKAN}

Andre, Orina. (2013). Pengaruh Profitabilitas, Likuiditas dan Leverage dalam Memprediksi Financial Distress. Padang: Jurnal Akuntansi Universitas Negeri Padang Vol.1 No.1.

Brigham, Eugene F., dan Houston, Joel. (2009). Fundamentals of Financial Management. Tenth Edition. Cengage Learning Asia Pte Ltd.

Damayanti. (2013). Pengaruh Struktur Aktiva, Ukuran Perusahaan, Peluang Bertumbuh dan Profitabilitas Terhadap Struktur Modal (Studi Pada Perusahaan Farmasi yang Terdaftar di Bursa Efek Indonesia). Jurnal Perspektif Bisnis, Vol 1, No 1, Juni 2013.

Horne, James C. Van dan John M. Machowicz, (2009). Prinsip-Prinsip Manajemen Keuangan: Alih bahasa Dewi Fitriasari dan Deny A.Kwary. Jakarta: Salemba Empat.

Husnan, Suad dan Pudjiastuti, Enny. (2012). Dasar-dasar Manajement Keuangan. Edisi keenam. Yogyakarta: UPP STIM YKPN. 
Jufrizen, (2014). Pengaruh Perputaran Kas dan Perputaran Persediaan Terhadap Profitabilitas pada Perusahaan Plastik dan Kemasan yang Terdaftar di BEI. Jurnal Ilmu Ekonomi Universitas Muhammadiyah Sumatera Utara, Vol. 14 No. 2.

Mireku, Kwame, Samuel Mensah dan Ogoe Emmanuel. (2014). The Relationship between Capital Structure Measures and Financial Performance: Evidence from Ghana. International Journal of Business and Management Vol. 9 No. 6.

Munawir, S. (2007). Analisa Laporan Keuangan. Edisi keempat, cetakan keempatbelas. Yogyakarta: Liberty.

Riyanto, B. (2011). Dasar-dasar Pembelanjaan Perusahaan. Edisi keempat, cetakan kesebelas. Yogyakarta: BPFE Universitas Gadjah Mada.

Rodoni, Ahmad dan Indoyama Nasaruddin. (2007). "Modul Manajemen Keuangan", Penerbit FEIS UIN, Jakarta.

Rosa, Marvina dan Mulyani, Erly. (2013). Pengaruh Profitabilitas Terhadap Return Saham Perusahaan Manufaktur Yang Terdaftar Di BEI. WRA. Vol 1.

Sartono, Agus. (2010). Manajemen Keuangan Teori dan Aplikasi. Edisi Keempat. Yogyakarta: BPFE.

Sjahrial, Dermawan. (2008). Manajemen Keuangan. Penerbit Mitra wacana media, Jakarta.

Weston, J, Fred. (1997). Manajemen Keuangan. Jakarta: Penerbit Erlangga.

Wibowo, Agus dan Wartini, Sri. Efisiensi Likuiditas dan Leverage terhadap Profitabilitas pada Perusahaan Manufaktur di BEI. Jurnal Dinamika Manajemen Universitas Negeri Semarang Vol. 3 No. 1, 49 - 58.

Wicaksana, I Gede Ananditha. (2012). Pengaruh Cash Ratio, Debt to Equity Ratio, dan Return On Asset Terhadap Kebijakan Dividen Pada Perusahaan Manufaktur Di Bursa Efek Indonesia. Denpasar: Tesis Program Pasca Sarjana Universitas Udayana.

Wiranata, Yulius Ardy dan Nugrahanti, Yeterina Widi (2013). Pengaruh Struktur Kepemilikan Terhadap Profitabilitas Perusahaan Manufaktur di Indonesia. Jurnal Akuntansi dan Keuangan Universitas Petra, Vol. 15, No. 1, 15-26. DOI: 10.9744/jak.15.1.15-26.

Zuhri, Mustanwir. (2015). Struktur Modal Perusahaan Determinan dan Implikasinya. Jakarta: Jurnal Manajemen dan Perbankan Vol.2 No.1 STIE-YAI. 